\title{
O IMPACTO DAS EXPORTAÇÕES NA PRODUÇÃO E DEMANDA POR MÃO DE OBRA NO BRASIL: UMA ANÁLISE A PARTIR DE UM MODELO MULTISSETORIAL ${ }^{1}$
}

\author{
Eduardo Santos Bourscheidt² \\ Carlos Eduardo Lobo e Silva ${ }^{3}$
}

\begin{abstract}
Este trabalho analisa os efeitos das exportações brasileiras sobre: i) a produção setorial e regional; e ii) a demanda por mão de obra. A análise dos efeitos das exportações considera os principais destinos dos produtos brasileiros, a partir de modelo multissetorial e da compatibilização e integração a esse modelo dos dados da Relação Anual de Informações Sociais (Rais), do Ministério da Economia (ME), e do sistema de base de dados AliceWeb, do Ministério da Indústria, Comércio Exterior e Serviços (MDIC). Os resultados mostram diferenças importantes no que concerne aos efeitos advindos da exportação para diferentes destinos. A comparação entre Estados Unidos e China é exemplar e contraria o esperado pela teoria Heckscher-Ohlin: enquanto a exportação para os Estados Unidos favorece especialmente o Sudeste e diversos setores de diferentes complexidades, exportações para a China favorecem o Centro-Oeste, em setores baseados em mão de obra não qualificada. Outra conclusão interessante está na dicotomia Estados UnidosArgentina versus China-União Europeia (UE). À medida que os efeitos das exportações para a Argentina se assemelham com os efeitos americanos, as exportações para a UE apresentam semelhança com os efeitos chineses.
\end{abstract}

Palavras-chave: economia internacional; exportações; matriz insumo-produto; economia brasileira.

\section{THE IMPACT OF EXPORTS ON PRODUCTION AND DEMAND FOR LABOR IN BRAZIL: AN ANALYSIS FROM A MULTISECTORAL MODEL}

This paper analyzes the effects of Brazilian exports on: i) sectoral and regional production; and ii) the demand for labor. The analysis of the effects of exports considers the main destinations of Brazilian products from a multisectoral model and the compatibility and integration of the data from the Annual Social Information Relation (Rais) and the Alice database system of the Ministry of Industry, Foreign Trade and Services. The results show important differences regarding the effects of exports to different destinations. The US-China comparison is exemplary and contrary to what is expected by the Heckscher-Ohlin theory: while exports to the US favor especially the southeast and several sectors of different complexities, exports to China favor the midwest in the hand-based sectors of unskilled labor. Another interesting conclusion is in the dichotomy USA / Argentina $x$ China / European Union. While the effects of exports to Argentina are similar to the American effects, exports to the European Union are similar to the Chinese effects.

Keywords: international economics; exports; input-output matrix; Brazilian economy.

1. DOI: http://dx.doi.org/10.38116/ppp56art3

2. Mestre em economia do desenvolvimento pela Pontíficia Universidade Católica do Rio Grande do Sul (PUC-RS).

E-mail:<eduardo.bourscheidt@outlook.com>.

3. Professor titular da PUC-RS. Pesquisador no Conselho Nacional de Desenvolvimento Científico e Tecnológico (CNPq).

E-mail: <carlos.silva@pucrs.br>. 


\section{EL IMPACTO DE LAS EXPORTACIONES EN LA PRODUCCIÓN Y LA DEMANDA DE TRABAJO EN BRASIL: UN ANÁLISIS DESDE UN MODELO MULTISECTORIAL}

En este trabajo se analizan los efectos de las exportaciones brasileñas en: i) la producción sectorial y regional; y ii) la demanda de trabajo. El análisis de los efectos de las exportaciones considera los principales destinos de los productos brasileños a partir de un modelo multisectorial y de la compatibilidad e integración a este modelo de los datos de la Relación Anual de Información Social (Rais) y del sistema de base de datos Alicia, Industria, Comercio Exterior y Servicios. Los resultados muestran diferencias importantes en relación a los efectos de la exportación a diferentes destinos. La comparación entre EE.UU. y China es ejemplar y contraria a lo esperado por la teoría HeckscherOhlin: mientras que la exportación a Estados Unidos favorece especialmente el sudeste y diversos sectores de diferentes complejidades, las exportaciones a China favorecen el centro-oeste, en sectores basados en mano de obra no cualificada. Otra conclusión interesante está en la dicotomía EE.UU./Argentina x China/Unión Europea. Mientras los efectos de las exportaciones a Argentina se asemejan a los efectos americanos, las exportaciones a la Unión Europea se asemejan a los efectos chinos.

Palabras clave: economía internacional; exportaciones; matriz insumo-producto; economía brasileña.

\section{L'IMPACT DES EXPORTATIONS SUR LA PRODUCTION ET LA DEMANDE DE TRAVAIL AU BRÉSIL: UNE ANALYSE À PARTIR D'UN MODĖLE MULTISECTORIEL}

Cet article analyse les effets des exportations brésiliennes sur: i) la production sectorielle et régionale; et ii) la demande de main-d'œuvre. L'analyse des effets des exportations considère les principales destinations des produits brésiliens à partir d'un modèle multisectoriel et la compatibilité et l'intégration des données de la Relation d'Information Sociale Annuelle (Rais) et du système de base de données Alice du Ministère de Industrie, commerce extérieur et services. Les résultats montrent des différences importantes en ce qui concerne les effets des exportations vers différentes destinations. La comparaison américano-chinoise est exemplaire et contraire à la théorie de Heckscher-Ohlin: alors que les exportations vers les États-Unis favorisent surtout le sud-est et plusieurs secteurs de complexités différentes, les exportations vers la Chine favorisent le midwest dans les secteurs manuels du travail non qualifié. Une autre conclusion intéressante est dans la dichotomie USA / Argentine x Chine / Union européenne. Alors que les effets des exportations vers I'Argentine sont similaires aux effets américains, les exportations vers I'Union européenne sont similaires aux effets chinois.

Mots-clés: économie internationale; exportations; matrice d'entrées-sorties; économie brésilienne.

JEL: C67; F00; F14; J20.

\section{INTRODUÇÃO}

Com um mundo cada vez mais globalizado e interligado, ${ }^{4}$ o número de transaçóes comerciais entre países cresce substancialmente. Esse crescimento tem se intensificado principalmente pelas mudanças na economia mundial, a partir principalmente da

4. Segundo o World Trade Statistical Review 2016, da Organização Mundial do Comércio - OMC (WTO, 2016), o volume de comércio internacional cresceu aproximadamente 60\%, de 2005 até 2015. 
metade do século XX. Segundo Neto, Azevedo e Portugal (2002), podem-se destacar: i) a formação do Acordo Geral de Comércio e Tarifas (GATT), com a intenção de reduzir as barreiras do comércio internacional; ii) o estabelecimento de diversos acordos preferenciais de comércio; e iii) a criação da Organização Mundial do Comércio.

O comércio internacional contribui não somente para o crescimento econômico de um país, como também para o aumento do nível de bem-estar da sua população. Ao manter-se a economia de um país fechada, sem interaçôes econômicas com demais países, cria-se uma série de limitaçóes de produção e consumo internos. Segundo Krugman e Obstfeld (2001), medidas protecionistas, como aumento dos impostos sobre importação e controle de câmbio rígido, podem contribuir para o crescimento da indústria nascente nacional; porém, prejudicam tanto os consumidores, que acabam tendo seu nível de escolha reduzido, como os produtores, por meio do seu potencial competitivo.

A partir principalmente da abertura comercial brasileira, iniciada nos anos 1990, o crescimento da importância das exportaçóes brasileiras na economia nacional é considerável. No entanto, De Negri (2005) ressalta que, enquanto o padrão de exportação mundial está mais concentrado em produtos intensivos em tecnologia, a pauta de exportaçôes brasileiras nos últimos anos apresenta grande participaçáo de bens de baixo teor tecnológico - ou seja, bens intensivos em trabalho, como bens agrícolas e recursos naturais.

Este trabalho tem como objetivo analisar os impactos na economia brasileira advindos das exportações do Brasil para alguns dos mais importantes destinos das exportaçóes brasileiras: Estados Unidos, China, Uniāo Europeia (UE), o continente africano e Argentina. A escolha de países e regióes de destino das exportaçôes brasileiras procurou incluir os principais parceiros comerciais do Brasil, incluindo-se as três maiores economias do mundo (Estados Unidos, China e UE) e o principal parceiro do Mercado Comum do Sul (Mercosul), além do continente africano, que servirá como referência de um parceiro cuja economia apresenta baixa intensidade de capital.

Além do impacto na economia nacional, o foco deste estudo está nos efeitos regionais e setoriais. Assim, o intuito é identificar os impactos das exportaçóes nas regióes/setores da economia brasileira, relacionando-os aos destinos dos nossos produtos e serviços.

Finalmente, o trabalho também integra, por intermédio da Relação Anual de Informaçôes Sociais (Rais), do Ministério da Economia (ME), a composição concernente à máo de obra de cada um dos setores da economia, o que permite relacionar os destinos das nossas importaçóes com as demandas regionais por mão de obra, considerando-se apenas dois tipos: i) qualificada; e ii) não qualificada. 
Há alguns estudos sobre o tema que utilizam metodologia semelhante à utilizada nesse trabalho, mas apresentam abordagem distinta com relação ao apresentado. Em geral, procuram apresentar os impactos das exportaçóes de determinado setor ou em determinada regiáo brasileira. Destaca-se o trabalho apresentado por Perobelli, Guilhoto e Faria (2006), que calcula os impactos na produção e no emprego nacionais para quatro blocos de comércio, no período 1997-2001.

Quanto à integração econômica das regiôes brasileiras, Perobelli e Haddad (2006) apresentam uma análise bastante detalhada e interessante das interações inter-regionais que ocorrem na economia, a partir de uma simulação de crescimento das exportaçóes brasileiras. Os autores tiveram como objetivo apresentar o impacto das exportaçóes de determinado estado sobre as exportaçóes dos demais estados, analisando a força de integração da produção nacional advinda das exportaçóes. Entre as principais conclusóes, os autores destacam que os estados da região Sudeste apresentam maior integração com o setor industrial e que as exportaçóes das regiốes Norte, Nordeste e Centro-Oeste revelam baixa integração com as demais regiōes brasileiras, localizando-se abaixo da média nacional.

O trabalho de Costa, Burnquist e Guilhoto (2006) analisa o impacto das alteraçóes das exportaçóes de açúcar e álcool das regiōes Centro-Sul e Norte-Nordeste. O objetivo do trabalho é, a partir de uma matriz insumo-produto (MIP), comparar os efeitos na economia de choques nas exportaçóes de cada um dos bens citados para as regióes, vendo assim em quais regióes eram encontrados efeitos mais expressivos. Os autores concluíram que, tanto para açúcar quanto para álcool, a regiâo Norte-Nordeste apresentou resultados mais expressivos, o que demonstra uma maior força desses setores na economia dessas regiōes.

Este artigo tem metodologia semelhante aos trabalhos citados anteriormente, especialmente Perobelli, Guilhoto e Faria (2006), porém com uma forma de abordar os resultados diferente. Utilizam-se as exportaçóes brasileiras para os destinos citados como base de dados, divididas por estado e setores para 2015 e emprega-se como metodologia uma matriz insumo-produto interestadual, elaborada por Guilhoto e Sesso Filho (2010).

Vale ressaltar ainda a semelhança metodológica deste trabalho com Fochezatto e Silva (2015), pois ambos utilizam um modelo intersetorial com a integração do modelo com outras bases. Ao contrário das exportaçôes, o foco de Fochezatto e Silva (2015) é o impacto oriundo do padrão de consumo dos brasileiros na produção regional.

\section{METODOLOGIA E DADOS}

O comércio internacional tem a capacidade de fomentar não somente a produção do setor exportador, como também a demanda desse setor por consumo intermediário dos demais setores da economia, gerando um ciclo de crescimento e influenciando 
diversos mercados de maneira simultânea. Com esse cenário em vista, os modelos multissetoriais tornam-se poderosos instrumentos para análise, pois têm a capacidade de captar as principais relaçóes entre os setores existentes no sistema.

A MIP é uma fotografia, pois representa a estrutura da economia de determinado país ou região em período de tempo fixo. Segundo Guilhoto (2001), é possível analisar os impactos e os efeitos na produçáo dos setores componentes da matriz, dada uma alteração positiva ou negativa na demanda final, que permite analisar o grau de encadeamento dos setores, sendo capaz de explorar os setores mais e menos influentes da economia em análise.

A partir da matriz inter-regional, o passo inicial é obter a matriz de coeficientes técnicos do consumo intermediário (CTCl). Essa matriz é obtida por meio da divisão de cada valor integrante da matriz, seja o consumo intermediário, seja o consumo das famílias ou remuneraçáo, pelo seu respectivo valor da produção apresentada na fórmula a seguir. Assim:

$$
C T C I_{i j}=\frac{X_{i j}}{V P_{j}} \text {. }
$$

Considerando-se $X$ o valor apresentado na matriz inter-regional e representando as linhas desta, cada valor de coeficiente técnico é definido a partir da divisão do valor da matriz inter-regional pelo valor da produção $(V P)$ representativa para cada setor de cada estado. Após o cálculo de todos os coeficientes, forma-se a matriz dos coeficientes técnicos $(M C T)$, importante para a continuação do processo.

Definidas a matriz dos coeficientes técnicos e a matriz-identidade, o próximo passo no tratamento para a obtenção da matriz-base para o choque das exportaçóes é a subtração da matriz-identidade da matriz dos coeficientes técnicos. A matriz resultante dessa subtração passa pelo processo de inversão - ou seja, a inversa da subtração da matriz identidade da matriz dos coeficientes técnicos do consumo intermediário. A equação 2 é conhecida como a matriz inversa de Leontief, representada a seguir:

$$
Y=(1-M C T)^{-1} \text {. }
$$

Com a matriz enfim definida, o passo seguinte fora calcular os efeitos das exportaçóes para os países ou regióes escolhidas na produção nacional, por meio da multiplicação da matriz pelo vetor das exportaçóes para cada destino determinado. Considere $B$ como o vetor do valor das exportaçôes brasileiras para determinado país ou regiâa, em reais. $\mathrm{O}$ resultado da multiplicação é considerado a matriz de impactos por setores e por estado, considere essa matriz como a matriz $Z$. Matematicamente:

$$
Z=B . Y \text {. }
$$

A partir da matriz $Z$ resultante, obtêm-se os impactos gerados na produção brasileira oriundos das exportaçóes dos setores de cada estado brasileiro para 
cada destino diferente. Os impactos dos diferentes destinos foram calculados de maneira separada - ou seja, os destinos de exportaçáo resultaram em um vetor cada, fazendo com que os impactos fossem diferentes em setores e regióes justamente pelas diferentes pautas de exportação de países e regiões analisados por esse trabalho. Após o cálculo dos impactos para cada estado brasileiro, optou-se pelo agrupamento dos estados em suas regiōes geográficas, com o intuito de fazer uma análise regional dos impactos.

Com a determinação da MIP com os dados dos estados brasileiros escolhida para ser utilizada como base para este trabalho, o próximo passo fora encontrar os dados disponíveis das exportaçóes brasileiras para os setores da matriz e os destinos a serem analisados pelo estudo. As exportaçóes brasileiras em 2015 foram as escolhidas, como a base de dados utilizada para análise, por serem as últimas exportaçóes de ano completo, visto que o atual ano do trabalho (2016) não possui ainda dados completos das exportaçóes; então, optou-se pelo ano anterior, com dados completos, de janeiro a dezembro.

Os dados das exportaçóes brasileiras foram encontrados no Ministério da Indústria, Comércio Exterior e Serviços (MDIC), no sistema de base de dados AliceWeb, do governo federal, e filtrados por estado exportador, país - ou região destino das exportaçóes e setor. Os dados colhidos do sistema AliceWeb têm seus valores apresentados em moeda corrente americana, o dólar. Buscando-se trazer para a moeda local, o real, para que a análise pudesse ser feita em moeda brasileira, foi feita a conversão dos valores das exportações em dólares para reais. Para não se gerar algum viés nos valores convertidos, fez-se a conversão dos valores em dólares pela média do valor do dólar em 2015.

Com a intenção de sincronizar os setores apresentados pela matriz insumo-produto utilizada no trabalho, com os setores dados pela Nomenclatura Comum do Mercosul (NCM), foi preciso fazer o agrupamento de setores da NCM, com o objetivo de compatibilizar com os setores da matriz. Sob a alcunha dessa nomenclatura, encontram-se 97 setores, os quais se encaixam por semelhança nos quinze setores produtivos utilizados para a MIP - os demais setores que compóem os 26 setores da matriz insumo-produto são setores ligados a serviços, cujos valores foram considerados zeros, pois o trabalho visa às exportaçóes dos setores produtivos.

A partir da análise dos setores da NCM e dos setores da matriz, foi possível organizá-los de tal maneira que os 97 setores apresentados sob a forma da NCM fossem agrupados nos quinze setores produtivos da MIP de maneira coerente e intuitiva, pela qual se pode abranger todos os setores com dados disponíveis para exportaçóes no sistema AliceWeb, do MDIC.

O quadro A.1, disponível no apêndice A, mostra como foram agrupados os setores da NCM, a fim de se obter os setores mais compactos apresentados pela 
MIP. A análise da tabela mostra-se importante para a obtenção do conhecimento de quais setores da NCM estão agrupados em qual setor da matriz, facilitando-se assim o conhecimento de quais são os componentes de cada setor analisado e impactado pelos efeitos que seráo explicitados no resultado dos efeitos.

A numeração ao lado dos setores é a mesma utilizada para obter o valor das exportaçóes referentes a determinado setor no sistema AliceWeb, podendo-se agrupar mais de um setor para facilitar a obtenção das exportaçóes brasileiras. Porém, a tarefa de conseguir os dados por estado e setor mantém-se responsável por grande parte do tempo de elaboração deste trabalho.

Para a análise do impacto das exportaçóes na demanda por mão de obra nacional, foram utilizados dados da Rais para mão de obra, filtrada por escolaridade - separando-se os trabalhadores desde analfabetos a com doutorado - e por setor - por meio da Classificação Nacional de Atividades Econômicas (CNAE 2.0). Assim como para o valor das exportaçóes, foi feito o agrupamento de alguns setores da CNAE, com o objetivo de que fossem compatibilizados com a MIP utilizados.

A escolaridade dos trabalhadores fora dividida entre qualificada e náo qualificada. A mão de obra qualificada abrange todos os trabalhadores que possuem ensino superior completo, mestrado ou ainda doutorado. Por sua vez, a mão de obra não qualificada inclui todos os trabalhadores que náo possuem ensino superior completo, agregando desde os trabalhadores analfabetos até os com ensino superior incompleto.

A partir dos dados de mão de obra agrupados por escolaridade e por setor e do seu valor de produção total, encontra-se a quantidade de trabalhadores necessários para cada real produzido, dividindo-se o número de trabalhadores do setor - qualificados e não qualificados - pelo valor total da produção, disponível na MIP - somando-se o valor de produçấo do mesmo setor em todos os estados brasileiros.

Ao obter-se o valor da quantidade de trabalhadores (qualificados e não qualificados) necessário para cada real produzido para cada setor, torna-se possível calcular o impacto de uma alteração no valor exportado pelo Brasil para cada destino e fazer uma análise de como a demanda por mão de obra se comporta mediante esse impacto.

\section{AS EXPORTAÇÕES BRASILEIRAS E SEUS IMPACTOS}

Dividem-se os resultados apresentados por este artigo em três grupos. Inicialmente, apresenta-se uma comparaçáo entre a participaçáo do valor total exportado por cada região brasileira para cada destino (efeito direto) e o impacto total que a exportação gera para as regióes. A comparação permite identificar casos nos quais, por exemplo, uma região é grande exportadora, mas demanda de outras regióes bens intermediá- 
rios para a produção do montante exportado. Nesse caso, o impacto aparentemente concentrado na região exportadora, de fato, distribui-se entre as demais regióes. Em seguida, são apresentados os principais resultados: impactos setoriais e regionais por destino. Assim, a análise procura destacar não apenas a região mais impactada, mas também quais os setores regionais que mais se beneficiam das exportaçóes.

Por fim, o último grupo analisa os efeitos de um aumento das exportaçóes na demanda por mão de obra regional. Os resultados são apresentados setorialmente para cada regiáo brasileira, separado por destino - ou seja, o impacto na demanda regional de mão de obra no tocante a uma maior incidência de exportaçóes para cada país ou bloco analisado.

Os valores apresentados são interpretados como o aumento do número de trabalhadores no setor causado pela elevação de $1 \%$ das exportaçóes para o respectivo destino.

A comparação entre a participação regional nas exportaçôes brasileiras por destinos e os impactos encontrados regionalmente mostra algumas disparidades interessantes. A tabela 1 revela os efeitos na produçáo total das regióes brasileiras advindos das exportaçóes por destino. A coluna EXP apresenta a participação no total exportado, enquanto a coluna EF traz a participação no aumento de produção total - considerados os efeitos indiretos - como resultado da exportação.

TABELA 1

Comparação entre a participação das exportações e a participação do efeito (2015) (Em \%)

\begin{tabular}{|c|c|c|c|c|c|c|c|c|c|c|}
\hline \multirow{2}{*}{ Região } & \multicolumn{2}{|c|}{ Estados Unidos } & \multicolumn{2}{|c|}{ África } & \multicolumn{2}{|c|}{ China } & \multicolumn{2}{|c|}{ União Europeia } & \multicolumn{2}{|c|}{ Argentina } \\
\hline & EXP & $\mathrm{EF}$ & EXP & $E F$ & EXP & EF & EXP & $\mathrm{EF}$ & EXP & $\mathrm{EF}$ \\
\hline Norte & 3,1 & 3,4 & 4,1 & 3,8 & 7,9 & 5,4 & 9,8 & 6,3 & 1,6 & 2,7 \\
\hline Nordeste & 8,6 & 9,1 & 5,2 & 7,2 & 9,8 & 10,2 & 9,8 & 10,0 & 8,7 & 8,9 \\
\hline $\begin{array}{l}\text { Centro- } \\
\text {-Oeste }\end{array}$ & 1,7 & 3,6 & 16,7 & 12,6 & 20,2 & 14,0 & 12,3 & 10,3 & 2,0 & 3,2 \\
\hline Sudeste & 72,8 & 68,1 & 51,3 & 53,9 & 37,2 & 47,8 & 49,5 & 53,5 & 65,4 & 64,3 \\
\hline Sul & 13,8 & 15,8 & 22,7 & 22,5 & 24,9 & 22,7 & 18,6 & 19,9 & 22,3 & 20,8 \\
\hline Total & 100 & 100 & 100 & 100 & 100 & 100 & 100 & 100 & 100 & 100 \\
\hline
\end{tabular}

Fontes: Resultados da pesquisa e AliceWeb.

Mais de $72 \%$ das exportaçôes que se destinam aos Estados Unidos são originárias da região Sudeste. Entretanto, do total da produção gerada pela exportação, apenas $68,1 \%$ estâo nessa regiáo, justamente o contrário do que ocorre com todas as outras regióes brasileiras - o impacto total é sempre maior que a participação regional nas exportaçóes para os Estados Unidos.

Nas exportações brasileiras para a China, a relação entre participação e efeito total inverte-se para Sudeste e Centro-Oeste. Enquanto a participação do Centro-Oeste salta 
para $20,2 \%$, o impacto total fica em $14,0 \%$. No caso do Sudeste, apenas $37,2 \%$ do total exportado se origina nessa regiáo - a menor participação de todos os destinos -, mas o impacto total no Sudeste ultrapassa os $47 \%$.

Considerando-se a UE, vale destacar que Norte e Nordeste apresentam a mesma participação nas exportaçóes $(9,8 \%)$; entretanto, o efeito total segue direçóes opostas: no Nordeste, amplia-se para 10\%, enquanto no Norte o impacto representa apenas $6,3 \%$ do total nacional.

$\mathrm{Na}$ comparação de cada região com os destinos das exportaçóes brasileiras, outro ponto interessante de análise é a região Nordeste. A participação do efeito na região é sempre ligeiramente maior que a participação das exportaçóes na pauta para qualquer que seja o país-destino.

Os resultados mostram que uma possível expansão das exportações com a China, mantendo a participação dos setores/regionais, seria especialmente benéfica para a regiāo Centro-Oeste, enquanto para os Estados Unidos os efeitos de expansão se concentrariam na região Sudeste.

A análise dos efeitos setoriais causados pelas exportaçóes mostra uma nítida diferenciação. Enquanto as exportaçóes que têm como destino os Estados Unidos e a Argentina apresentam fortes impactos nos setores de materiais de transporte e metalurgia - setores com maior complexidade industrial -, as exportaçôes para África, China e UE apresentam forte impacto nos setores agrícola e alimentício (setores menos complexos).

TABELA 2

Participação dos setores por destino (2015)

\begin{tabular}{|c|c|c|}
\hline \multicolumn{3}{|c|}{ Estados Unidos } \\
\hline Posição & Setor & Setor $(\%)$ \\
\hline $1 \stackrel{0}{1}$ & Metalurgia & 11,3 \\
\hline $2^{\circ}$ & Material de transporte & 7,8 \\
\hline $3^{0}$ & Alimentos, bebidas e fumo & 7,0 \\
\hline \multicolumn{3}{|c|}{ África } \\
\hline Posição & Setor & Setor $(\%)$ \\
\hline 10 & Alimentos, bebidas e fumo & 18,8 \\
\hline $2^{\circ}$ & Agricultura, silvicultura e exploração florestal & 11,3 \\
\hline $3^{\circ}$ & Pecuária e pesca & 10,0 \\
\hline \multicolumn{3}{|c|}{ China } \\
\hline Posição & Setor & Setor $(\%)$ \\
\hline 10 & Agricultura, silvicultura e exploração florestal & 21,1 \\
\hline $2^{\circ}$ & Mineração & 12,6 \\
\hline $3^{\circ}$ & Refino de petróleo, coque e álcool & 8,7 \\
\hline \multicolumn{3}{|c|}{ União Europeia } \\
\hline Posição & Setor & Setor $(\%)$ \\
\hline
\end{tabular}




\begin{tabular}{llc} 
(Continuação) & & \\
\hline $1^{\circ}$ & Alimentos, bebidas e fumo & 12,6 \\
$2^{\circ}$ & Agricultura, silvicultura e exploração florestal & 10,9 \\
$3^{\circ}$ & Metalurgia & 8,4 \\
\hline & & Argentina \\
\hline Posição & Setor & Setor (\%) \\
\hline $1^{\circ}$ & Material de transporte & 18,5 \\
$2^{\circ}$ & Metalurgia & 9,0 \\
$3^{\circ}$ & Outros produtos químicos e farmacêuticos & 7,9 \\
\hline
\end{tabular}

Fonte: Resultados da pesquisa.

O setor de metalurgia é o setor que apresenta os maiores efeitos diretos e indiretos nas exportaçóes dos Estados Unidos, representando 11,3\% do efeito registrado. Esse destaque se dá muito por conta desse setor na regiáo Sudeste, que, em uma análise total por setor e região - considerando-se os 130 setores; ou seja, os 26 setores de cada uma das cinco regióes -, apresenta 9,2\% do total dos efeitos, sendo o setor mais afetado direta e indiretamente na produção pelas exportaçóes para o país norte-americano. Seguindo essa linha, o setor de materiais de transporte aparece como segundo setor de maior impacto na produção, também principalmente pelas exportaçóes do setor da regiáo Sudeste, aparecendo como segundo setor com maior participação no país.

\subsection{Efeitos sobre a produção}

Nesta subseção, serão apresentados os impactos nas regiōes brasileiras para cada destino analisado. Os resultados apresentados são o impacto, em reais, das exportaçóes da regiấo com o aumento de $1 \%$ nas exportaçóes para cada destino. Além do crescimento absoluto em reais, serão apresentadas também tabelas com as variações percentuais das exportações setoriais.

\subsubsection{Região Norte}

Os impactos das exportações na região Norte concentram-se, em grande parte, nos produtos agrícolas e na mineração (tabela 3). Com sua pauta exportadora prioritariamente desses produtos, um aumento das exportaçóes da região gera um crescimento significativo desses setores. Na tabela 3, estáo destacados em cinza os valores mais significativos para o resultado. Com um aumento de $1 \%$ das exportaçóes para a China, por exemplo, o setor de mineraçáo tem impacto positivo superior a $\mathrm{R} \$ 37$ milhóes de produção. O segundo maior valor da tabela também diz respeito ao crescimento da produçẫo da mineração, nesse caso como resultado de aumento da exportaçáo brasileira para a UE, que afeta também de forma significativa o setor agrícola. 
TABELA 3

Impactos na região Norte (2015)

(Em R\$ mil)

\begin{tabular}{lrrrrr}
\hline \multicolumn{1}{c}{ Setores } & Estados Unidos & África & China & União Europeia & Argentina \\
\hline Agricultura, silvicultura e exploração florestal & 279 & 238 & 3.815 & 9.744 & 6 \\
Pecuária e pesca & 22 & 705 & 9 & 7 & 0,01 \\
Mineração & 241 & 0 & 37.782 & 31.495 & 1 \\
Alimentos, bebidas e fumo & 44 & 0 & - & 90 & 2 \\
Têxtil, vestuário e calçados & 1 & 0 & 504 & 135 & 0 \\
Madeira, papel e impressão & 260 & 1 & 147 & 532 & 3 \\
Refino de petróleo, coque e álcool & - & - & - & - & - \\
Outros produtos químicos e farmacêuticos & 1.551 & 8 & 105 & 328 & 39 \\
Artigos de borracha e plástico & 1 & 0 & 0 & 1 & 4 \\
Cimento e outros produtos de minerais não & 0 & - & - & 0 & 0 \\
metálicos & 162 & 0 & 83 & 861 & 21 \\
Metalurgia & 2 & 0 & 0 & 3 \\
Máquinas e equipamentos & 3 & 0 & 1 & 1 & 16 \\
Material elétrico e eletrônicos & 17 & 1 & 0 & 0 & 104 \\
Material de transporte & 1 & 0 & 0 & 15 \\
Indústrias diversas & & & \\
\hline
\end{tabular}

Fonte: Resultados da pesquisa.

Outros impactos importantes podem ser apontados: produtos químicos e farmacêuticos quando se aumentam as exportaçóes para os Estados Unidos; agrícolas e pecuária e pesca no caso da África como destino; e materiais de transporte para aumento das exportaçóes para a Argentina. Em linhas gerias, vale ressaltar que, em valores absolutos e no caso da regiấo Norte, destacam-se os impactos nos produtos primários advindos das exportaçóes para a China e a UE.

Com a análise percentual, apresentada na tabela 4, é possível obter a magnitude relativa do impacto de crescimento do aumento de $1 \%$ das nossas exportaçóes. Novamente, os principais destaques são os setores de mineração e agricultura, quando consideradas as exportaçóes para a China e a UE. O setor de mineração apresenta crescimento de $0,54 \%$, dado um aumento de $1 \%$ das exportaçóes para a China, sendo o valor mais destacado da análise. 
TABELA 4

Impactos na região Norte (2015)

(Em \%)

\begin{tabular}{lccccc}
\hline Setores & Estados Unidos & África & China & União Europeia & Argentina \\
\hline Agricultura, silvicultura e exploração florestal & 0,08 & 0,07 & 0,25 & 0,37 & 0,02 \\
Pecuária e pesca & 0,03 & 0,10 & 0,04 & 0,06 & 0,01 \\
Mineração & 0,06 & 0,01 & 0,54 & 0,49 & 0,01 \\
Alimentos, bebidas e fumo & 0,03 & 0,02 & - & 0,06 & 0,01 \\
Têxtil, vestuário e calçados & 0,03 & 0,01 & 0,29 & 0,16 & 0,01 \\
Madeira, papel e impressão & 0,07 & 0,01 & 0,06 & 0,10 & 0,02 \\
Refino de petróleo, coque e álcool & - & - & - & - & - \\
Outros produtos químicos e farmacêuticos & 0,35 & 0,03 & 0,12 & 0,19 & 0,06 \\
Artigos de borracha e plástico & 0,04 & 0,01 & 0,04 & 0,05 & 0,04 \\
Cimento e outros produtos de minerais não metálicos & 0,02 & - & - & 0,02 & 0,01 \\
Metalurgia & 0,05 & 0,01 & 0,04 & 0,10 & 0,02 \\
Máquinas e equipamentos & 0,02 & 0,00 & 0,02 & 0,03 & 0,04 \\
Material elétrico e eletrônicos & 0,01 & 0,00 & 0,01 & 0,02 & 0,02 \\
Material de transporte & 0,03 & 0,01 & 0,02 & 0,02 & 0,05 \\
Indústrias diversas & 0,02 & 0,01 & 0,02 & 0,03 & 0,04 \\
\hline
\end{tabular}

Fonte: Resultados da pesquisa.

Seguindo o encontrado na tabela 4, o setor mais impactado pelo aumento de $1 \%$ das exportaçóes para os Estados Unidos é o de produtos químicos e farmacêuticos, com $0,35 \%$. Nas exportaçôes para a África e a Argentina, não se tem um valor significativo para a análise, sendo os crescimentos, em suma, menores que $0,1 \%$.

\subsubsection{Região Nordeste}

Os impactos na região Nordeste têm estrutura setorial diferente (tabela 5), em comparação aos setores da regiáo Norte. O setor madeireiro é o de maior destaque, principalmente se considerando aumentos de exportação para a China e a União Europeia. Em seguida, aparecem os impactos na agricultura, também como consequência de variação positiva das exportaçôes para a China e a UE. Ainda para as exportaçóes com destino à China, os setores de máquinas e equipamentos e metalurgia apresentam grande impacto, mostrando também a força da região não apenas em produtos primários.

TABELA 5

Impactos na região Nordeste (2015)

(Em R\$ mil)

\begin{tabular}{lccccc}
\hline \multicolumn{1}{c}{ Setores } & Estados Unidos & África & China & União Europeia & Argentina \\
\hline Agricultura, silvicultura e exploração florestal & 296 & 30 & 8.864 & 5.706 & 6 \\
Pecuária e pesca & 158 & 4 & 1 & 24 & - \\
Mineração & 38 & 5 & 332 & 158 & 4 \\
Alimentos, bebidas e fumo & 307 & 219 & 34 & 1.678 & 73 \\
\hline
\end{tabular}




\begin{tabular}{lccccc}
\hline \multicolumn{1}{c}{ Setores } & Estados Unidos & África & China & União Europeia & Argentina \\
\hline Têxtil, vestuário e calçados & 255 & 15 & 225 & 525 & 103 \\
Madeira, papel e impressão & 1.361 & 5 & 13.018 & 12.506 & 0 \\
Refino de petróleo, coque e álcool & 229 & 0 & 1 & 141 & 2 \\
Outros produtos químicos e farmacêuticos & 783 & 51 & 191 & 997 & 648 \\
Artigos de borracha e plástico & 1.064 & 6 & 72 & 448 & 212 \\
Cimento e outros produtos de minerais não & 10 & 0 & 0 & 1 & 0 \\
metálicos & 1.045 & 15 & 3.572 & 267 & 358 \\
Metalurgia & 2 & 0 & 3.547 & 15 & 2 \\
Máquinas e equipamentos & 0 & 0 & 189 & 52 & 57 \\
Material elétrico e eletrônicos & 2 & 0 & 1 & 0 & 0 \\
Material de transporte & 0 & 0 & 0 & 0 & 062 \\
Indústrias diversas & & & & \\
\hline
\end{tabular}

Fonte: Resultados da pesquisa.

No caso do aumento das exportaçóes para os Estados Unidos, os setores mais impactados são o madeireiro, o de artigos de borracha, bem como o de plástico e metalurgia. Para a Argentina, o destaque encontra-se nos setores de material de transporte e de produtos químicos e farmacêuticos. Diferentemente das exportaçóes para a China e a UE, as vendas brasileiras para a Argentina e os Estados Unidos não apresentam crescimentos destacados para os setores agrícola e de mineração, o que evidencia uma diferença na pauta entre os destinos.

$\mathrm{Na}$ análise percentual, o principal destaque está nos setor de madeira, papel e impressão. Nas exportaçóes para a China e a UE, acréscimo de $1 \%$ gera aumento de $0,46 \%$ e $0,45 \%$ da produção, respectivamente. Para os Estados Unidos, o setor madeireiro também tem destaque, seguido pelo setor de borracha e plástico próximo. No caso da Argentina como destino, material de transporte é o mais impactado, assim como acontece na região Norte.

TABELA 6

Impactos na região Nordeste (2015)

(Em \%)

\begin{tabular}{lccccc}
\hline \multicolumn{1}{c}{ Setores } & Estados Unidos & África & China & União Europeia & Argentina \\
\hline Agricultura, silvicultura e exploração florestal & 0,05 & 0,02 & 0,20 & 0,18 & 0,02 \\
Pecuária e pesca & 0,05 & 0,03 & 0,03 & 0,07 & - \\
Mineração & 0,05 & 0,02 & 0,09 & 0,08 & 0,03 \\
Alimentos, bebidas e fumo & 0,04 & 0,03 & 0,03 & 0,09 & 0,02 \\
Têxtil, vestuário e calçados & 0,05 & 0,01 & 0,05 & 0,07 & 0,03 \\
Madeira, papel e impressão & 0,16 & 0,01 & 0,46 & 0,45 & 0,01 \\
Refino de petróleo, coque e álcool & 0,06 & 0,01 & 0,06 & 0,07 & 0,02 \\
\hline
\end{tabular}


(Continuação)

\begin{tabular}{lccccc}
\hline \multicolumn{1}{c}{ Setores } & Estados Unidos & África & China & União Europeia & Argentina \\
\hline Outros produtos químicos e farmacêuticos & 0,09 & 0,03 & 0,10 & 0,12 & 0,07 \\
Artigos de borracha e plástico & 0,15 & 0,02 & 0,07 & 0,12 & 0,08 \\
Cimento e outros produtos de minerais não & 0,02 & 0,00 & 0,02 & 0,02 & 0,01 \\
metálicos & 0,10 & 0,01 & 0,18 & 0,06 & 0,06 \\
Metalurgia & 0,02 & 0,01 & 0,40 & 0,04 & 0,02 \\
Máquinas e equipamentos & 0,01 & 0,00 & 0,07 & 0,04 & 0,04 \\
Material elétrico e eletrônicos & 0,01 & 0,00 & 0,02 & 0,02 & 0,11 \\
Material de transporte & 0,01 & 0,00 & 0,02 & 0,02 & 0,01 \\
Indústrias diversas & & & & \\
\hline
\end{tabular}

Fonte: Resultados da pesquisa.

\subsubsection{Região Centro-Oeste}

Considerando-se a regiáo Centro-Oeste, o crescimento de $1 \%$ das exportaçôes para a China gera impacto destacado no setor agrícola ( $\mathrm{R}$ \$ 118 milhóes), representando um aumento de $0,61 \%$ do total. Têxtil e madeireireiro são os setores que também apresentam repercussão significativa.

Com relação às exportaçôes para a UE, três setores se destacam com igual importância: agricultura, alimentos e madeira. Na questáo da participação percentual, no entanto, o setor madeireiro lidera com crescimento de $0,53 \%$.

TABELA 7

Impactos na região Centro-Oeste (2015)

(Em R\$ mil)

\begin{tabular}{|c|c|c|c|c|c|}
\hline Setores & Estados Unidos & África & China & União Europeia & Argentina \\
\hline Agricultura, silvicultura e exploração florestal & 50 & 2.340 & 118.665 & 6.867 & 1 \\
\hline Pecuária e pesca & 7 & 1.479 & 964 & 2.315 & 1 \\
\hline Mineração & 6 & 1 & 103 & 854 & 1.284 \\
\hline Alimentos, bebidas e fumo & 36 & 163 & 78 & 6.964 & 2 \\
\hline Têxtil, vestuário e calçados & 97 & 1 & 3.733 & 961 & 1 \\
\hline Madeira, papel e impressão & 608 & 27 & 5.988 & 7.528 & 31 \\
\hline Refino de petróleo, coque e álcool & 0 & - & - & - & - \\
\hline Outros produtos químicos e farmacêuticos & 21 & 6 & 43 & 92 & 12 \\
\hline Artigos de borracha e plástico & 0 & 0 & - & 1 & 0 \\
\hline Cimento e outros produtos de minerais não metálicos & 0 & 0 & 0 & 0 & - \\
\hline Metalurgia & 193 & 0 & 1.206 & 2.841 & 6 \\
\hline Máquinas e equipamentos & 5 & 2 & - & 0 & 1 \\
\hline Material elétrico e eletrônicos & 1 & 0 & - & 0 & 1 \\
\hline Material de transporte & 0 & 0 & - & 0 & 3 \\
\hline Indústrias diversas & 0 & 0 & 0 & 1 & 0 \\
\hline
\end{tabular}

Fonte: Resultados da pesquisa. 
Para a região Centro-Oeste, e considerando-se a África como destino de nossas exportaçóes, há impactos importantes nos setores agrícola e pecuário. Por sua vez, as exportaçóes para os Estados Unidos repercutem fortemente na produção do setor madeireiro. Finalmente, a mineração é o setor de destaque nas exportaçóes destinadas à Argentina, e, seguindo uma lógica inversa, a Argentina é o destino que traz o maior impacto de todos os analisados para o setor brasileiro de mineração.

TABELA 8

Impactos na região Centro-Oeste (2015)

(Em \%)

\begin{tabular}{lccccc}
\hline Setores & Estados Unidos & África & China & União Europeia & Argentina \\
\hline Agricultura, silvicultura e exploração florestal & 0,03 & 0,10 & 0,61 & 0,18 & 0,01 \\
Pecuária e pesca & 0,03 & 0,11 & 0,10 & 0,17 & 0,01 \\
Mineração & 0,04 & 0,02 & 0,09 & 0,19 & 0,22 \\
Alimentos, bebidas e fumo & 0,02 & 0,03 & 0,04 & 0,14 & 0,01 \\
Têxtil, vestuário e calçados & 0,06 & 0,01 & 0,37 & 0,20 & 0,01 \\
Madeira, papel e impressão & 0,16 & 0,04 & 0,47 & 0,53 & 0,04 \\
Refino de petróleo, coque e álcool & 0,03 & - & - & - & - \\
Outros produtos químicos e farmacêuticos & 0,04 & 0,04 & 0,20 & 0,11 & 0,02 \\
Artigos de borracha e plástico & 0,03 & 0,02 & - & 0,08 & 0,03 \\
Cimento e outros produtos de minerais não metálicos & 0,02 & 0,00 & 0,02 & 0,02 & - \\
Metalurgia & 0,08 & 0,01 & 0,18 & 0,27 & 0,03 \\
Máquinas e equipamentos & 0,03 & 0,01 & - & 0,03 & 0,01 \\
Material elétrico e eletrônicos & 0,02 & 0,01 & - & 0,02 & 0,02 \\
Material de transporte & 0,01 & 0,01 & - & 0,02 & 0,01 \\
Indústrias diversas & 0,01 & 0,01 & 0,03 & 0,03 & 0,01 \\
\hline
\end{tabular}

Fonte: Resultados da pesquisa.

$\mathrm{Na}$ questão percentual, a China e a União Europeia apresentam os grandes destaques da análise, com o setor agrícola para a China e o setor madeireiro para a UE, com $0,61 \%$ e $0,53 \%$, respectivamente. Nas exportaçóes argentinas, o setor novamente destacado é o setor de mineração, com crescimento de 0,22\%, também se destacando como o mais importante crescimento de setor.

\subsubsection{Região Sudeste}

Os impactos das nossas exportaçôes na região Sudeste - região que apresenta os maiores aumentos de produção - estão concentrados no setores de mineração e de refino de petróleo - no caso da China, como destino - e agrícola e metalurgia, nas exportações para a UE. 
Finalmente, metalurgia e material de transporte são também bastante impactados pelas exportaçóes, respectivamente, aos Estados Unidos e à Argentina.

\section{TABELA 9}

Impactos na região Sudeste (2015)

(Em R\$ mil)

\begin{tabular}{lccccc}
\hline Setores & Estados Unidos & África & China & União Europeia & Argentina \\
\hline Agricultura, silvicultura e exploração florestal & 3.616 & 152 & 7.054 & 24.030 & 52 \\
Pecuária e pesca & 64 & 1.092 & 891 & 831 & 6 \\
Mineração & 460 & 77 & 34.818 & 5.693 & 178 \\
Alimentos, bebidas e fumo & 2.152 & 3.778 & 1.375 & 5.563 & 58 \\
Têxtil, vestuário e calçados & 201 & 11 & 385 & 281 & 150 \\
Madeira, papel e impressão & 2.499 & 19 & 962 & 3.537 & 163 \\
Refino de petróleo, coque e álcool & 6.765 & 23 & 26.489 & 3.156 & 8 \\
Outros produtos químicos e farmacêuticos & 1.228 & 101 & 250 & 2.752 & 989 \\
Artigos de borracha e plástico & 640 & 43 & 183 & 1.136 & 1.776 \\
Cimento e outros produtos de minerais não metálicos & 3.360 & 5 & 30 & 111 & 124 \\
Metalurgia & 13.558 & 279 & 501 & 17.095 & 1.387 \\
Máquinas e equipamentos & 2.695 & 182 & 89 & 3.283 & 1.671 \\
Material elétrico e eletrônicos & 497 & 18 & 39 & 161 & 489 \\
Material de transporte & 9.064 & 223 & 121 & 492 & 13.947 \\
Indústrias diversas & 216 & 5 & 1 & 132 & 58 \\
\hline
\end{tabular}

Fonte: Resultados da pesquisa.

O Sudeste é a região que apresenta os maiores valores absolutos, em reais, do impacto das exportaçóes. Tal fato é oriundo principalmente do grande volume de produtos produzidos pela região, assim como da imporância geral da região para o país. Percebe-se também que quase todos os setores têm destaque para algum dos destinos analisados, mostrando como todos os setores da região são impactados fortemente por um aumento das exportaçóes brasileiras.

TABELA 10

Impactos na região Sudeste (2015)

(Em \%)

\begin{tabular}{lccccc}
\hline \multicolumn{1}{c}{ Setores } & Estados Unidos & África & China & União Europeia & Argentina \\
\hline Agricultura, silvicultura e exploração florestal & 0,10 & 0,03 & 0,14 & 0,25 & 0,02 \\
Pecuária e pesca & 0,04 & 0,08 & 0,08 & 0,10 & 0,02 \\
Mineração & 0,06 & 0,01 & 0,22 & 0,10 & 0,02 \\
Alimentos, bebidas e fumo & 0,05 & 0,06 & 0,05 & 0,09 & 0,02 \\
Têxtil, vestuário e calçados & 0,04 & 0,01 & 0,05 & 0,05 & 0,03 \\
Madeira, papel e impressão & 0,08 & 0,01 & 0,06 & 0,11 & 0,03 \\
Refino de petróleo, coque e álcool & 0,10 & 0,01 & 0,19 & 0,09 & 0,02 \\
Outros produtos químicos e farmacêuticos & 0,06 & 0,02 & 0,08 & 0,09 & 0,04 \\
\hline
\end{tabular}




\begin{tabular}{lccccc}
\hline \multicolumn{1}{c}{ Setores } & Estados Unidos & África & China & União Europeia & Argentina \\
\hline Artigos de borracha e plástico & 0,07 & 0,02 & 0,05 & 0,08 & 0,09 \\
$\begin{array}{l}\text { Cimento e outros produtos de minerais não } \\
\text { metálicos }\end{array}$ & 0,12 & 0,01 & 0,02 & 0,03 & 0,03 \\
Metalurgia & 0,12 & 0,02 & 0,04 & 0,13 & 0,05 \\
Máquinas e equipamentos & 0,07 & 0,02 & 0,02 & 0,08 & 0,05 \\
Material elétrico e eletrônicos & 0,04 & 0,01 & 0,02 & 0,03 & 0,04 \\
Material de transporte & 0,09 & 0,02 & 0,02 & 0,03 & 0,11 \\
Indústrias diversas & 0,04 & 0,01 & 0,02 & 0,04 & 0,02 \\
\hline
\end{tabular}

Fonte: Resultados da pesquisa.

Nos impactos percentuais, poucos setores destacam-se no caso da região Sudeste. O maior crescimento percentual é do setor agrícola nas exportaçóes para a UE (0,25\% para o aumento de $1 \%$ das exportaçôes). Vale destacar também que, para as exportaçóes destinadas à China, mineração, refino de petróleo e agricultura apresentam crescimento de $0,22 \%, 0,19 \%$ e $0,14 \%$, respectivamente.

\subsubsection{Região Sul}

Da mesma maneira que para as demais regióes brasileiras, o setor agrícola aparece como destaque no impacto de um aumento das exportaçóes para a China. No tocante à região Sul, esse setor é o destaque principal da análise dos impactos; fato que pode ser explicado pela pauta de exportaçáo para o país asiático ser voltada significativamente para produtos agrícolas.

Por sua vez, nas exportaçôes para os Estados Unidos, os efeitos são maiores em setores de máquinas e equipamentos e outros produtos químicos, além do setor madeireiro, principal destaque do destino.

TABELA 11

Impactos na região Sul (2015)

(Em R\$ mil)

\begin{tabular}{lccccc}
\hline \multicolumn{1}{c}{ Setores } & Estados Unidos & África & China & União Europeia & Argentina \\
\hline Agricultura, silvicultura e exploração florestal & 58 & 593 & 117.996 & 915 & 4 \\
Pecuária e pesca & 59 & 1.192 & 1.457 & 2.898 & 18 \\
Mineração & 2 & 0 & 2 & 3 & 1 \\
Alimentos, bebidas e fumo & 353 & 506 & 421 & 12.069 & 32 \\
Têxtil, vestuário e calçados & 405 & 10 & 221 & 1.130 & 126 \\
Madeira, papel e impressão & 2.980 & 53 & 818 & 1.825 & 543 \\
Refino de petróleo, coque e álcool & 89 & 0 & 0 & 18 & 27 \\
Outros produtos químicos e farmacêuticos & 464 & 26 & 187 & 1.133 & 244 \\
Artigos de borracha e plástico & 224 & 21 & 251 & 1.513 & 1.710 \\
Cimento e outros produtos de minerais não & 139 & 3 & 0 & 11 & 31 \\
metálicos & 340 & 18 & 52 & 170 & 330 \\
Metalurgia & & & & & (Continua)
\end{tabular}




\begin{tabular}{lccccc}
\hline \multicolumn{1}{c}{ Setores } & Estados Unidos & África & China & União Europeia & Argentina \\
\hline Máquinas e equipamentos & 737 & 59 & 53 & 999 & 796 \\
Material elétrico e eletrônicos & 249 & 28 & 25 & 380 & 87 \\
Material de transporte & 94 & 71 & 818 & 73 & 3.467 \\
Indústrias diversas & 388 & 15 & 2 & 253 & 22 \\
\hline
\end{tabular}

Fonte: Resultados da pesquisa.

As exportações para a África apresentam impacto destacado nos setores de agricultura, pecuária e alimentos, de maneira semelhante às demais regiôes do país. Para a UE, os dois efeitos mais destacados são nos setores de alimentos e pecuária, porém diversos setores apresentam impactos relevantes. Nas exportaçôes para a Argentina, material de transporte - mais uma vez - e artigos de borracha e plástico são os principais setores impactados.

TABELA 12

Impactos na região Sul (2015)

(Em \%)

\begin{tabular}{|c|c|c|c|c|c|}
\hline Setores & Estados Unidos & África & China & União Europeia & Argentina \\
\hline Agricultura, silvicultura e exploração florestal & 0,03 & 0,05 & 0,51 & 0,10 & 0,01 \\
\hline Pecuária e pesca & 0,04 & 0,08 & 0,09 & 0,15 & 0,02 \\
\hline Mineração & 0,05 & 0,02 & 0,06 & 0,07 & 0,03 \\
\hline Alimentos, bebidas e fumo & 0,03 & 0,03 & 0,04 & 0,13 & 0,01 \\
\hline Têxtil, vestuário e calçados & 0,05 & 0,01 & 0,05 & 0,08 & 0,03 \\
\hline Madeira, papel e impressão & 0,13 & 0,02 & 0,08 & 0,11 & 0,06 \\
\hline Refino de petróleo, coque e álcool & 0,04 & 0,02 & 0,08 & 0,06 & 0,02 \\
\hline Outros produtos químicos e farmacêuticos & 0,06 & 0,03 & 0,14 & 0,11 & 0,05 \\
\hline Artigos de borracha e plástico & 0,06 & 0,02 & 0,07 & 0,14 & 0,14 \\
\hline Cimento e outros produtos de minerais não metálicos & 0,05 & 0,01 & 0,02 & 0,02 & 0,03 \\
\hline Metalurgia & 0,06 & 0,02 & 0,04 & 0,06 & 0,06 \\
\hline Máquinas e equipamentos & 0,05 & 0,02 & 0,02 & 0,06 & 0,05 \\
\hline Material elétrico e eletrônicos & 0,04 & 0,01 & 0,02 & 0,05 & 0,03 \\
\hline Material de transporte & 0,03 & 0,02 & 0,06 & 0,03 & 0,11 \\
\hline Indústrias diversas & 0,06 & 0,01 & 0,03 & 0,05 & 0,02 \\
\hline
\end{tabular}

Fonte: Resultados da pesquisa.

Percentualmente, considerando-se a China como destino, o setor agrícola apresenta o maior valor. O crescimento de $1 \%$ das exportaçóes para o país asiático gera aumento de $0,51 \%$ na produçáo do setor. Para os demais destinos, os impactos destacados ficam em torno de $0,14 \%$ de aumento, com destaque para o setor de artigos de borracha, que apresenta esse percentual para dois destinos: UE e Argentina. 


\subsection{Efeitos na mão de obra}

Os resultados da demanda por mão de obra afetada pelo aumento das exportações para China, África e UE mostraram um crescimento destacado da demanda, principalmente nos setores de agricultura e alimentos, para todas as regióes brasileiras, com destaque para a região Centro-Oeste, na qual um aumento de $1 \%$ das exportaçóes para a China foi responsável pelo acréscimo de mais de 1.012 trabalhadores não qualificados para o setor agrícola. Além do destaque dos setores agrícola e alimentício de forma geral, alguns destaques regionais podem ser citados, como o impacto na demanda por trabalhadores no setor de mineração, da região Norte; o no setor madeireiro, no Nordeste; o no setor têxtil, no Sudeste; e o no setor de pecuária, na região Sul.

TABELA 13

Impactos na mão de obra da região Centro-Oeste (2015)

\begin{tabular}{|c|c|c|c|c|c|c|c|c|c|c|}
\hline \multirow{2}{*}{ Setores } & \multicolumn{2}{|c|}{ Estados Unidos } & \multicolumn{2}{|c|}{ África } & \multicolumn{2}{|c|}{ China } & \multicolumn{2}{|c|}{ União Europeia } & \multicolumn{2}{|c|}{ Argentina } \\
\hline & $Q^{1}$ & $\mathrm{NQ}^{2}$ & Q & NQ & Q & NQ & Q & NQ & Q & NQ \\
\hline $\begin{array}{l}\text { Agricultura, silvicultura e explora- } \\
\text { ção florestal }\end{array}$ & 0,30 & 8,03 & 4,76 & 126,56 & 38,04 & 1012,37 & 7,31 & 194,54 & 0,02 & 0,66 \\
\hline Pecuária e pesca & 0,04 & 1,36 & 1,86 & 71,79 & 1,32 & 50,91 & 1,86 & 71,58 & 0,02 & 0,66 \\
\hline Mineração & 0,02 & 0,09 & 0,01 & 0,05 & 0,17 & 0,63 & 0,63 & 2,40 & 0,86 & 3,26 \\
\hline Alimentos, bebidas e fumo & 0,51 & 6,79 & 1,90 & 25,38 & 0,59 & 7,94 & 16,08 & 215,11 & 0,05 & 0,70 \\
\hline Têxtil, vestuário e calçados & 0,65 & 16,63 & 0,03 & 0,90 & 4,23 & 108,80 & 2,08 & 53,52 & 0,03 & 0,82 \\
\hline Madeira, papel e impressão & 1,45 & 15,26 & 0,29 & 3,03 & 4,79 & 50,38 & 5,41 & 56,84 & 0,30 & 3,15 \\
\hline Refino de petróleo, coque e álcool & 0,00 & 0,00 & 0,00 & 0,00 & 0,00 & 0,00 & 0,00 & 0,00 & 0,00 & 0,00 \\
\hline $\begin{array}{l}\text { Outros produtos químicos e } \\
\text { farmacêuticos }\end{array}$ & 0,24 & 0,67 & 0,07 & 0,19 & 0,10 & 0,28 & 0,39 & 1,07 & 0,25 & 0,68 \\
\hline Artigos de borracha e plástico & 0,00 & 0,01 & 0,00 & 0,00 & 0,00 & 0,00 & 0,01 & 0,12 & 0,01 & 0,09 \\
\hline $\begin{array}{l}\text { Cimento e outros produtos de } \\
\text { minerais não metálicos }\end{array}$ & 0,00 & 0,01 & 0,00 & 0,01 & 0,00 & 0,00 & 0,00 & 0,00 & 0,00 & 0,00 \\
\hline Metalurgia & 0,32 & 2,02 & 0,00 & 0,01 & 0,89 & 5,66 & 1,41 & 8,91 & 0,03 & 0,20 \\
\hline Máquinas e equipamentos & 0,11 & 0,75 & 0,08 & 0,52 & 0,00 & 0,00 & 0,01 & 0,06 & 0,04 & 0,27 \\
\hline Material elétrico e eletrônicos & 0,01 & 0,07 & 0,01 & 0,03 & 0,00 & 0,00 & 0,00 & 0,00 & 0,02 & 0,11 \\
\hline Material de transporte & 0,00 & 0,00 & 0,00 & 0,01 & 0,00 & 0,00 & 0,00 & 0,00 & 0,07 & 0,35 \\
\hline Indústrias diversas & 0,00 & 0,00 & 0,00 & 0,00 & 0,00 & 0,00 & 0,01 & 0,16 & 0,02 & 0,31 \\
\hline
\end{tabular}

Fonte: Resultados da pesquisa.

Notas: ${ }^{1}$ Mão de obra qualificada.

${ }^{2}$ Mão de obra não qualificada.

Por sua vez, as exportaçóes para os Estados Unidos apresentaram um impacto mais diversificado nos setores de mão de obra, registrando efeitos distintos entre as regióes brasileiras. $\mathrm{O}$ grande destaque está na regiáo Sudeste, que apresenta valores destacados de crescimento de trabalhadores náo qualificados para diversos setores, principalmente 
para os de cimento, material de transporte, agricultura e alimentos, registrando acréscimo de mais de 226, 192, 184 e 175 trabalhadores não qualificados na regiáo, respectivamente. Em destaque nas demais regióes, estão os setores madeireiro na região Norte, os setores têxtil, madeireiro e alimentício nas regiōes Nordeste e Centro-Oeste, bem como os setores têxtil e de maquinas e equipamentos, na regiáo Sul.

TABELA 14

Impactos na mão de obra da região Sudeste (2015)

\begin{tabular}{|c|c|c|c|c|c|c|c|c|c|c|}
\hline \multirow{2}{*}{ Setores } & \multicolumn{2}{|c|}{ Estados Unidos } & \multicolumn{3}{|c|}{ África } & \multirow{2}{*}{$\frac{\text { China }}{\text { NQ }}$} & \multicolumn{2}{|c|}{ União Europeia } & \multicolumn{2}{|c|}{ Argentina } \\
\hline & Q & NQ & Q & NQ & Q & & Q & NQ & Q & NQ \\
\hline $\begin{array}{l}\text { Agricultura, silvicultura e } \\
\text { exploração florestal }\end{array}$ & 6,93 & 184,35 & 0,91 & 24,20 & 9,64 & 256,54 & 18,80 & 500,17 & 0,55 & 14,60 \\
\hline Pecuária e pesca & 0,22 & 8,45 & 1,79 & 69,00 & 1,48 & 57,02 & 1,13 & 43,67 & 0,06 & 2,20 \\
\hline Mineração & 1,06 & 4,01 & 0,77 & 2,92 & 22,65 & 85,99 & 8,05 & 30,54 & 1,11 & 4,20 \\
\hline Alimentos, bebidas e fumo & 13,10 & 175,33 & 20,31 & 271,78 & 8,64 & 115,57 & 20,40 & 272,90 & 1,15 & 15,44 \\
\hline Têxtil, vestuário e calçados & 2,15 & 55,35 & 0,39 & 10,09 & 3,05 & 78,48 & 2,22 & 57,06 & 2,15 & 55,41 \\
\hline Madeira, papel e impressão & 11,20 & 117,73 & 0,57 & 5,99 & 5,60 & 58,80 & 12,69 & 133,33 & 2,15 & 22,56 \\
\hline $\begin{array}{l}\text { Refino de petróleo, coque e } \\
\text { álcool }\end{array}$ & 20,02 & 48,16 & 0,46 & 1,11 & 41,57 & 100,02 & 10,73 & 25,81 & 0,11 & 0,27 \\
\hline $\begin{array}{l}\text { Outros produtos químicos e } \\
\text { farmacêuticos }\end{array}$ & 10,27 & 27,95 & 2,24 & 6,10 & 1,54 & 4,20 & 14,20 & 38,62 & 11,02 & 29,99 \\
\hline Artigos de borracha e plástico & 4,98 & 57,78 & 1,16 & 13,49 & 2,13 & 24,73 & 7,31 & 84,69 & 10,44 & 121,05 \\
\hline $\begin{array}{l}\text { Cimento e outros produtos de } \\
\text { minerais não metálicos }\end{array}$ & 13,39 & 226,27 & 0,35 & 5,89 & 0,71 & 11,91 & 1,66 & 28,08 & 2,11 & 35,69 \\
\hline Metalurgia & 15,10 & 95,59 & 1,88 & 11,93 & 1,87 & 11,86 & 17,35 & 109,85 & 3,45 & 21,86 \\
\hline Máquinas e equipamentos & 24,64 & 162,17 & 6,36 & 41,84 & 2,62 & 17,24 & 26,91 & 177,14 & 19,67 & 129,48 \\
\hline Material elétrico e eletrônicos & 5,96 & 30,77 & 0,95 & 4,92 & 0,94 & 4,86 & 2,61 & 13,47 & 6,14 & 31,68 \\
\hline Material de transporte & 40,78 & 192,59 & 5,84 & 27,59 & 2,67 & 12,60 & 6,91 & 32,62 & 51,43 & 242,89 \\
\hline Indústrias diversas & 2,68 & 41,46 & 0,27 & 4,19 & 0,03 & 0,43 & 1,70 & 26,33 & 1,33 & 20,54 \\
\hline
\end{tabular}

Fonte: Resultados da pesquisa.

Os resultados encontrados para as exportaçóes para a Argentina apresentaram característica distinta em comparação com as demais analisadas. Os resultados foram centralizados nos setores mais complexos para todas as regiôes brasileiras, principalmente para os setores de material de transporte e máquinas e equipamentos. Apesar dos acréscimos menores em comparação com os demais destinos, um destaque pode ser dado para o setor de material de transporte da regiáo Sudeste, com acréscimo de mais de 242 trabalhadores não qualificados para o setor da região. Regionalmente, destacam-se os setores de artigos de borracha e plástico e têxtil nas regiôes Nordeste, Sudeste e Sul. Nas regiōes Norte e Centro-Oeste, os impactos na demanda por mão de obra das exportaçóes para a Argentina não apresentaram grande destaques. 
De maneira geral, os resultados obtidos apresentaram aumento mais importante da demanda por mão de obra nos setores de menor complexidade industrial - ou seja, os setores agrícolas, alimentício e madeireiro para todas as regióes analisadas. Além disso, o impacto na demanda por mão de obra foi concentrado especialmente na mão de obra não qualificada brasileira, o que reforça o baixo capital humano encontrado no Brasil.

Por fim, construindo conexôes entre o comportamento das relaçôes comerciais brasileiras e seus impactos com as tradicionais teorias do comércio internacional, encontram-se alguns resultados divergentes com o previsto pelas teorias. A atenção aqui é especialmente na teoria Heckscher-Ohlin, segundo a qual o país exporta os bens cuja produção utiliza os fatores abundantes na economia exportadora.

Curiosamente, enquanto nossas exportaçôes para os Estados Unidos favorecem a economia do Sudeste, exportaçóes para a China beneficiam especialmente o Centro-Oeste. Portanto, as exportaçóes para um país relativamente intensivo em capital têm impulsionado a região brasileira mais intensiva em capital.

\section{CONSIDERAÇÕES FINAIS}

A comparação dos efeitos causados em cada regiâo, considerando-se o destino das exportaçóes, indica como possíveis acordos comerciais podem impactar as regiôes brasileiras.

Uma breve comparação entre as duas maiores economias do mundo mostra-nos a diferença dos efeitos causados pelas exportaçoos para ambos os países. Enquanto as exportaçóes para os Estados Unidos apresentam maiores impactos tanto na produção quanto na mão de obra mais centralizadas na regiâo Sudeste do país, as exportaçóes para a China tendem a causar efeitos menos centralizados na regiáo. Entretanto, nos setores em que a demanda por mão de obra é mais afetada, as exportações para a China são muito mais centralizadas nos setores mais agrícolas e de alimentos, enquanto as exportaçóes para os Estados Unidos estimulam uma gama de setores maior que as exportaçóes para o país asiático.

De maneira geral, e como deveríamos esperar em função da nossa pauta de exportação, o setor agrícola é sempre muito impactado com um aumento das exportações para a China. Além deste, e ainda se considerando as compras chinesas, os setores de pecuária, mineração e alimentos revelam também índices significativos para quase todas as regióes brasileiras. Semelhante ao que acontece com as exportaçóes para a China, as exportaçóes que se destinam ao continente africano apresentam altos impactos nos setores de agricultura e alimentos.

Por sua vez, as exportaçóes para os Estados Unidos, apesar de diferenciadas, apresentam um setor de destaque em comum para todas as regióes brasileiras: madeira, papel e impressão. Também vale mencionar os impactados no setor de 
metalurgia, principalmente impulsionado pelas exportações da região Sudeste. Resultados similares aos advindos da exportação para os Estados Unidos aparecem quando são analisadas as exportaçôes brasileiras para a Argentina, que traz uma especificidade: impactos significativos no setor de material de transportes.

Finalmente, as consequências setoriais das exportaçóes à UE dependem da regiáo brasileira analisada: enquanto no Sudeste os impactos se assemelham àqueles decorrentes das exportaçôes para os Estados Unidos, nas demais regióes os efeitos setoriais assemelham-se aos impactos consequentes das exportaçóes para a China.

Além do impacto na produção nacional, o modelo identifica impactos das exportaçóes no aumento da demanda por mão de obra. O crescimento das exportaçóes para a China, a UE e a regiáo africana trouxeram maiores impactos na demanda por mão de obra dos setores menos complexos, como agricultura e pecuária. Por sua vez, o crescimento das exportaçóes para os Estados Unidos e a Argentina trouxe maiores impactos na demanda por mão de obra dos setores mais complexos, como máquinas e equipamentos e materiais de transporte. Na questão da qualidade da mão de obra, todas as exportaçóes se mostraram muito impactantes na mão de obra não qualificada, abundante no país. O destaque positivo da mão de obra qualificada está nas exportaçôes para a China, porém em setores intensivos em mão de obra não qualificada.

Uma interessante conclusão está na dicotomia entre Estados Unidos e China. Enquanto os efeitos das exportaçóes para a nação norte-americana têm seus efeitos em produção concentrados fortemente na regiáo Sudeste e mais diversificados pelo Brasil na mão de obra, os efeitos na produção das exportaçôes para a China são mais variados entre as regiōes, mas se concentrando em setor específico (setor agrícola), enquanto os efeitos na mão de obra são centralizados nesta. Essa dicotomia mostra dois cenários distintos nos efeitos, impactando diretamente uma escolha de políticas internacionais.

Por fim, os resultados apresentados por este trabalho podem contribuir para a criação de possíveis políticas públicas de fomento ao comércio internacional brasileiro, demonstrando o comportamento da produção nacional e do aumento da demanda por mão de obra de possíveis acordos com os principais destinos dos bens produzidos nacionalmente. Além disso, permite que se façam simulaçóes nas variáveis, a fim de analisar o comportamento da economia brasileira como um todo, a partir de impactos específicos no comércio internacional brasileiro. 


\section{REFERÊNCIAS}

ARAÚJO, B. C. P. O. Análise empírica dos efeitos ex-post das exportações sobre a produtividade, emprego e renda das empresas brasileiras. In: ASSOCIAÇÃO NACIONAL DOS CENTROS DE PÓS-GRADUAÇÃO EM ECONOMIA, 34., 2006, Salvador, Bahia. Anais... Salvador: Anpec, 2006. p. 1-20.

BALASSA, B. An empirical demonstration of classical comparative cost theory. The Review of Economics and Statistics, Massachusetts, v. 45, n. 3, p. 231-238, Aug. 1963.

. Trade liberazition and "revealed" comparative advantage. The Manchester School of Economic and Social Studies, v. 33, n. 2, p. 99-123, May 1965.

. Tariff reductions and trade in manufactures among the industrial countries. The American Economic Review, v. 56, n. 3, p. 466-473, June 1966.

COSTA, C. C.; BURNQUIST, H. L.; GUILHOTO, J. J. M. Impacto de alteraçóes nas exportaçóes de açúcar e álcool nas regióes Centro-Sul e Norte-Nordeste sobre a economia do Brasil. Revista de Economia \& Sociologia Rural, Rio de Janeiro, v. 44, n. 4, p. 609-627, out./dez. 2006.

DE NEGRI, F. Conteúdo tecnológico do comércio exterior brasileiro: o papel das empresas estrangeiras. Rio de Janeiro: Ipea, 2005. (Texto para Discussão, n. 1074). FEENSTRA R. C. Advanced international trade. Princeton: Princeton University Press, 2004.

FEIJÓ, C. A. et al. Contabilidade social: o novo sistema de Contas Nacionais do Brasil. 2. ed. Rio de Janeiro: Atlas, 2003.

FIGUEIREDO, A. M.; SANTOS, M. L. Evolução das vantagens comparativas do Brasil no comércio de soja. Revista de Política Agrícola, Brasília, v. 14, n. 1, p. 9-16, jan./fev./ mar. 2005.

GUILHOTO J. J. M. Leontief and input-output: background principles and evolution. São Paulo: Esalq/USP, 2001. (Texto para Discussão, n. 15).

GUILHOTO, J. J. M.; SESSO FILHO, U. A. Estimação da matriz insumo-produto a partir de dados preliminares das Contas Nacionais. Economia Aplicada, v. 9, n. 2, p. 277-299, abr./jun. 2005.

. Estimação da matriz insumo-produto utilizando dados preliminares das Contas Nacionais: aplicação e análise de indicadores econômicos para o Brasil em 2005. Economia \& Tecnologia, ano 6, v. 23, p. 53-62, out./dez. 2010.

GUILHOTO, J. J. M. et al. Matriz de insumo-produto do Nordeste e estados: metodologia e resultados. Fortaleza: BNB, 2010. 289 p. 
KRAAY, A. Exports and economic performance: evidence from a panel of Chinese enterprises. Washington: World Bank, 1999.

KRUGMAN, P. Trade and wages, reconsidered. Brookings Papers on Economic Activity, p. 103-154, Spring 2008.

KRUGMAN, P. R.; OBSTFELD, M. Economia Internacional: teoria e política. 5. ed. São Paulo: Makron Books, 2001.

LEAMER, E, E. The Leontief paradox, reconsidered. Journal of Political Economy, v. 88, n. 3, p. 495-503, 1980.

LEONTIEF, W. W. Domestic production and foreign trade: the American capital position re-examined. Proceedings of the American Philosophical Society, v. 57, n. 4. p. 332-349, 28 Sept. 1953.

MILLER, R. E.; BLAIR, P. D. Input-output analysis: foundations and extensions. New Jersey: Prentice Hall, 1985.

NETO, P. C. F. B.; AZEVEDO, A. F. Z.; PORTUGAL, M. S. Impactos comerciais da área de livre comércio das Américas: uma aplicação do modelo gravitacional. Porto Alegre: PPGE/UFRGS, 2002. (Texto para Discussão, n. 9).

PEROBELLI, F. S.; GUILHOTO, J. J. M.; FARIA, W. R. Impacto das exportaçóes brasileiras para o Mercosul, Uniāo Europeia e Nafta sobre produção e emprego: uma análise de insumo produto para 1997-2001. In: SOCIEDADE BRASILEIRA DE ECONOMIA, ADMINISTRACAO E SOCIOLOGIA RURAL (SOBER), 44., 2006, Fortaleza, Ceará. Anais... Fortaleza: Sober, 2006. p. 1-20.

PEROBELLI, F. S.; HADDAD, E. A. Exportaçôes internacionais e interaçóes regionais: uma análise de equilíbrio geral. Estudos Econômicos, São Paulo, v. 36, n. 4, p. 833-866, out./dez. 2006.

RICARDO, D. Princípios de economia política e tributaçáo. São Paulo: Abril Cultural, 1982 (1817). (Coleção Os Economistas).

VANEK, J. The factor proportions theory: the n-factor case. Kiklos, v. 21, n. 4, p. 749-754, 1968.

WTO - WORLD TRADE ORGANIZATION. World Trade Statistical Review 2016. Geneva: WTO, 2016. 163 p. Disponível em: <https://bit.ly/36xsU4g>. Acesso em: 22 fev. 2017.

SITE

ALICEWEB. Séries temporais. Disponível em: <http://comexstat.mdic.gov.br/ pt/geral>. Acesso em: 5 fev. 2017. 


\section{APÊNDICE A}

\section{COMPATIBILIZAÇÃO DOS SETORES}

QUADRO A.1

\section{Padronização da Nomenclatura Comum do Mercosul (NCM)}

\begin{tabular}{|c|c|}
\hline \multirow{9}{*}{$\begin{array}{l}\text { Agricultura, silvicultura e } \\
\text { exploração florestal }\end{array}$} & $\begin{array}{l}\text { 6. Plantas vivas e produtos de floricultura } \\
\text { 7. Produtos hortícolas, plantas, raízes e tubérculos, comestíveis }\end{array}$ \\
\hline & 8. Frutas; cascas de frutos cítricos e de melões \\
\hline & 9. Café, chá, mate e especiarias \\
\hline & 10. Cereais \\
\hline & 11. Produtos da indústria de moagem; malte; amidos e féculas; inulina; e glúten de trigo \\
\hline & $\begin{array}{l}\text { 12. Sementes e frutos oleaginosos; grãos, sementes e frutos diversos; plantas industriais ou } \\
\text { medicinais; e palhas e forragens }\end{array}$ \\
\hline & 13. Gomas, resinas e outros sucos e extratos vegetais \\
\hline & $\begin{array}{l}\text { 14. Materiais para entrançar e outros produtos de origem vegetal, não especificados nem } \\
\text { compreendidos em outros capítulos }\end{array}$ \\
\hline & $\begin{array}{l}\text { 15. Gorduras e óleos animais ou vegetais; produtos da sua dissociação; gorduras alimentares } \\
\text { elaboradas; e ceras de origem animal ou vegetal }\end{array}$ \\
\hline \multirow{5}{*}{ Pecuária e pesca } & 1. Animais vivos \\
\hline & 2. Carnes e miudezas, comestíveis \\
\hline & 3. Peixes e crustáceos, moluscos e outros invertebrados aquáticos \\
\hline & $\begin{array}{l}\text { 4. Leite e lacticínios; ovos de aves; mel natural; produtos comestíveis de origem animal não } \\
\text { especificados nem compreendidos em outros capítulos }\end{array}$ \\
\hline & 5. Outros produtos de origem animal, não especificados nem compreendidos em outros capítulos \\
\hline \multirow{2}{*}{ Mineração } & 25. Sal; enxofre; terras e pedras; e gesso, cal e cimento \\
\hline & 26. Minérios, escórias e cinzas \\
\hline
\end{tabular}


(Continuação)

\begin{tabular}{|l|l|}
\hline \multirow{5}{*}{ Alimentos, bebidas e fumo } & 16. Preparações de carne, de peixes ou de crustáceos, de moluscos ou de outros invertebrados \\
\cline { 2 - 3 } & 17. Açúcares e produtos de confeitaria \\
\cline { 2 - 3 } & 18. Cacau e suas preparações \\
\hline \multirow{5}{*}{ 19. Preparações à base de cereais, farinhas, amidos, féculas ou leite; produtos de pastelaria } \\
\hline & 20. Preparações de produtos hortícolas, de frutas ou de outras partes de plantas \\
\cline { 2 - 3 } & 21. Preparações alimentícias diversas \\
\cline { 2 - 3 } & 22. Bebidas, líquidos alcoólicos e vinagres \\
\hline & 23. Resíduos e desperdícios das indústrias alimentares; alimentos preparados para animais \\
\hline & 24. Tabaco e seus sucedâneos manufaturados \\
\hline
\end{tabular}


(Continuação)

\begin{tabular}{|c|c|}
\hline & 41. Peles, exceto as peles com pelo, e couros \\
\hline & $\begin{array}{l}\text { 42. Obras de couro; artigos de correeiro ou de seleiro; artigos de viagem, bolsas e artefatos } \\
\text { semelhantes; e obras de tripa }\end{array}$ \\
\hline & 43. Peles com pelo e suas obras; e peles com pelo artificiais \\
\hline & 50. Seda \\
\hline & 51. Lã, pelos finos ou grosseiros; e fios e tecidos de crina \\
\hline & 52. Algodão \\
\hline & 53. Outras fibras têxteis vegetais; e fios de papel e tecidos de fios de papel \\
\hline & $\begin{array}{l}\text { 54. Filamentos sintéticos ou artificiais; e lâminas e formas semelhantes de materiais têxteis } \\
\text { sintéticas ou artificiais }\end{array}$ \\
\hline & 55. Fibras sintéticas ou artificiais, descontínuas \\
\hline & $\begin{array}{l}\text { 56. Pastas (ouates), feltros e falsos tecidos; fios especiais; cordéis, cordas e cabos; e artigos de } \\
\text { cordoaria }\end{array}$ \\
\hline & 57. Tapetes e outros revestimentos para pisos (pavimentos), de materiais têxteis \\
\hline \multirow{10}{*}{ Têxtil, vestuários e calçados } & 58. Tecidos especiais; tecidos tufados; rendas; tapeçarias; passamanarias; e bordados \\
\hline & $\begin{array}{l}\text { 59. Tecidos impregnados, revestidos, recobertos ou estratificados; artigos para usos técnicos de } \\
\text { materiais têxteis }\end{array}$ \\
\hline & 60. Tecidos de malha \\
\hline & 61. Vestuário e seus acessórios, de malha \\
\hline & 62. Vestuário e seus acessórios, exceto de malha \\
\hline & $\begin{array}{l}\text { 63. Outros artefatos têxteis confeccionados; sortidos; artefatos de materiais têxteis, calçados, } \\
\text { chapéus e artefatos de uso semelhante, usados; e trapos }\end{array}$ \\
\hline & 64. Calçados, polainas e artefatos semelhantes; e suas partes \\
\hline & 65. Chapéus e artefatos de uso semelhante; e suas partes \\
\hline & $\begin{array}{l}\text { 66. Guarda-chuvas; sombrinhas; guarda-sóis; bengalas; bengala-assentos; chicotes; pingalins; e } \\
\text { suas partes }\end{array}$ \\
\hline & 67. Penas e penugem preparadas e suas obras; flores artificiais; e obras de cabelo \\
\hline
\end{tabular}


(Continuação)

\begin{tabular}{|c|c|}
\hline \multirow{6}{*}{ Madeira, papel e impressão } & 44. Madeira, carvão vegetal e obras de madeira \\
\hline & 45. Cortiça e suas obras \\
\hline & 46. Obras de espartaria ou de cestaria \\
\hline & $\begin{array}{l}\text { 47. Pastas de madeira ou de outros materiais fibrosos celulósicos; e papel ou cartão para reciclar } \\
\text { (desperdícios e aparas) }\end{array}$ \\
\hline & 48. Papel e cartão; obras de pasta de celulose, de papel ou de cartão \\
\hline & $\begin{array}{l}\text { 49. Livros, jornais, gravuras e outros produtos das indústrias gráficas; e textos manuscritos ou } \\
\text { datilografados, planos e plantas }\end{array}$ \\
\hline $\begin{array}{l}\text { Refino de petróleo, coque e } \\
\text { álcool }\end{array}$ & $\begin{array}{l}\text { 27. Combustíveis minerais, óleos minerais e produtos da sua destilação; matérias betuminosas; } \\
\text { e ceras minerais }\end{array}$ \\
\hline \multirow{11}{*}{$\begin{array}{l}\text { Outros produtos químicos e } \\
\text { farmacêuticos }\end{array}$} & $\begin{array}{l}\text { 28. Produtos químicos inorgânicos; e compostos inorgânicos ou orgânicos de metais preciosos, } \\
\text { de elementos radioativos, de metais das terras raras ou de isótopos }\end{array}$ \\
\hline & 29. Produtos químicos orgânicos \\
\hline & 30. Produtos farmacêuticos \\
\hline & 31. Adubos (fertilizantes) \\
\hline & $\begin{array}{l}\text { 32. Extratos tanantes e tintoriais; taninos e seus derivados; pigmentos e outras matérias coran- } \\
\text { tes; tintas e vernizes mástiques; e tintas de escrever }\end{array}$ \\
\hline & $\begin{array}{l}\text { 33. Óleos essenciais e resinoides; e produtos de perfumaria ou de toucador preparados e } \\
\text { preparações cosméticas }\end{array}$ \\
\hline & $\begin{array}{l}\text { 34. Sabões; agentes orgânicos de superfície; preparações para lavagem; preparações lubrifi- } \\
\text { cantes; ceras artificiais; ceras preparadas; produtos de conservação e limpeza; velas e artigos } \\
\text { semelhantes; massas ou pastas para modelar; ceras para dentistas; e composições para dentistas } \\
\text { à base de gesso }\end{array}$ \\
\hline & $\begin{array}{l}\text { 35. Matérias albuminoides; produtos à base de amidos ou de féculas modificados; colas; e } \\
\text { enzimas }\end{array}$ \\
\hline & 36. Pólvoras e explosivos; artigos de pirotecnia; fósforos; ligas pirofóbicas; e matérias inflamáveis \\
\hline & 37. Produtos para fotografia e cinematografia \\
\hline & 38. Produtos diversos das indústrias químicas \\
\hline \multirow{2}{*}{ Artigos de borracha e plástico } & 39. Plástico e suas obras \\
\hline & 40. Borracha e suas obras \\
\hline \multirow{3}{*}{$\begin{array}{l}\text { Cimento e outros produtos de } \\
\text { minerais não metálicos }\end{array}$} & 68. Obras de pedra, gesso, cimento, amianto, mica ou de materiais semelhantes \\
\hline & 69. Produtos cerâmicos \\
\hline & 70. Vidro e suas obras \\
\hline
\end{tabular}


(Continuação)

\begin{tabular}{|c|c|}
\hline \multirow{13}{*}{ Metalurgia } & $\begin{array}{l}\text { 71. Pérolas naturais ou cultivadas; pedras preciosas ou semipreciosas e semelhantes; metais } \\
\text { preciosos; metais folheados ou chapeados de matais preciosos (plaquê) e suas obras; bijuterias; } \\
\text { e moedas }\end{array}$ \\
\hline & 72. Ferro fundido, ferro e aço \\
\hline & 73. Obras de ferro fundido, ferro ou aço \\
\hline & 74. Cobre e suas obras \\
\hline & 45. Níquel e suas obras \\
\hline & 76. Alumínio e suas obras \\
\hline & 77. Reservado para uma eventual utilização futura no sistema harmonizado \\
\hline & 78. Chumbo e suas obras \\
\hline & 79. Zinco e suas obras \\
\hline & 80. Estanho e suas obras \\
\hline & 81. Outros metais comuns; ceramais (cernets); e obras desses materiais \\
\hline & 82. Ferramentas; artefatos de cutelaria e talheres, e suas partes; e metais comuns \\
\hline & 83. Obras diversas de metais comuns \\
\hline \multirow[b]{2}{*}{ Máquinas e equipamentos } & 84. Reatores nucleares; caldeiras; máquinas; aparelhos e instrumentos mecânicos; e suas partes \\
\hline & $\begin{array}{l}\text { 90. Instrumentos e aparelhos de óptica, de fotografia, de cinematografia, de medida, de contro- } \\
\text { le ou de precisão; instrumentos e aparelhos médico-cirúrgicos; e suas partes e acessórios }\end{array}$ \\
\hline Material elétrico e eletrônicos & $\begin{array}{l}\text { 85. Máquinas, aparelhos e materiais elétricos, e suas partes; aparelhos de gravação ou de } \\
\text { reprodução de som; aparelhos de gravação ou de reprodução de imagens e de som em televisão; } \\
\text { e suas partes e acessórios }\end{array}$ \\
\hline \multirow{4}{*}{ Material de transporte } & $\begin{array}{l}\text { 86. Veículos e material para vias férreas ou semelhantes, e suas partes; aparelhos mecânicos - } \\
\text { incluindo-se os eletromecânicos - de sinalização para vias de comunicação }\end{array}$ \\
\hline & 87. Veículos automóveis; tratores; ciclos e outros veículos terrestres; e suas partes e acessórios \\
\hline & 88. Aeronaves e aparelhos espaciais, e suas partes \\
\hline & 89. Embarcações e estruturas flutuantes \\
\hline
\end{tabular}


(Continuação)

\begin{tabular}{|c|c|}
\hline \multirow{7}{*}{ Indústrias diversas } & 91. Artigos de relojoaria \\
\hline & 92. Instrumentos musicais, e suas partes e acessórios \\
\hline & 93. Armas e munições, e suas partes e acessórios \\
\hline & $\begin{array}{l}\text { 94. Móveis, mobiliário médico-cirúrgico; colchões, almofadas e semelhantes; aparelho de ilumi- } \\
\text { nação não especificada nem compreendida em outros capítulos; anúncios, cartazes ou tabuletas } \\
\text { e placas indicadoras, luminosos e artigos semelhantes; e construções pré-fabricadas }\end{array}$ \\
\hline & 95. Brinquedos, jogos, artigos para divertimento ou para esporte, e suas partes e acessórios \\
\hline & 96. Obras diversas \\
\hline & 97. Objetos de arte e de coleção e antiguidades \\
\hline
\end{tabular}

Fonte: NCM.

Elaboração dos autores.

TABELA A. 1

Impactos na mão de obra da região Norte (2015)

\begin{tabular}{|c|c|c|c|c|c|c|c|c|c|c|}
\hline \multirow{2}{*}{ Setores } & \multicolumn{2}{|c|}{ Estados Unidos } & \multicolumn{3}{|c|}{ África } & \multirow{2}{*}{$\frac{\text { China }}{\text { NQ }}$} & \multicolumn{2}{|c|}{ União Europeia } & \multicolumn{2}{|c|}{ Argentina } \\
\hline & $\mathrm{Q}$ & NQ & $Q$ & NQ & $Q$ & & Q & NQ & $\mathrm{Q}$ & NQ \\
\hline $\begin{array}{l}\text { Agricultura, silvicultura e exploração } \\
\text { florestal }\end{array}$ & 0,68 & 18,21 & 0,71 & 18,81 & 3,01 & 80,14 & 5,07 & 134,94 & 0,06 & 1,57 \\
\hline Pecuária e pesca & 0,09 & 3,46 & 0,97 & 37,33 & 0,04 & 1,39 & 0,02 & 0,61 & 0,00 & 0,00 \\
\hline Mineração & 0,62 & 2,37 & 0,00 & 0,02 & 10,16 & 38,56 & 9,17 & 34,83 & 0,01 & 0,05 \\
\hline Alimentos, bebidas e fumo & 0,45 & 5,96 & 0,00 & 0,00 & 0,00 & 0,00 & 0,48 & 6,40 & 0,06 & 0,82 \\
\hline Têxtil, vestuário e calçados & 0,01 & 0,31 & 0,00 & 0,00 & 0,74 & 19,14 & 0,35 & 9,10 & 0,00 & 0,01 \\
\hline Madeira, papel e impressão & 1,34 & 14,05 & 0,05 & 0,49 & 0,89 & 9,40 & 1,92 & 20,21 & 0,07 & 0,70 \\
\hline Refino de petróleo, coque e álcool & 0,00 & 0,00 & 0,00 & 0,00 & 0,00 & 0,00 & 0,00 & 0,00 & 0,00 & 0,00 \\
\hline $\begin{array}{l}\text { Outros produtos químicos e farmacêuti- } \\
\text { cos }\end{array}$ & 2,11 & 5,73 & 0,12 & 0,33 & 0,41 & 1,10 & 0,79 & 2,16 & 0,28 & 0,77 \\
\hline Artigos de borracha e plástico & 0,02 & 0,21 & 0,00 & 0,00 & 0,00 & 0,02 & 0,01 & 0,06 & 0,06 & 0,66 \\
\hline $\begin{array}{l}\text { Cimento e outros produtos de minerais } \\
\text { não metálicos }\end{array}$ & 0,00 & 0,01 & 0,00 & 0,00 & 0,00 & 0,00 & 0,00 & 0,02 & 0,00 & 0,00 \\
\hline Metalurgia & 0,43 & 2,71 & 0,00 & 0,00 & 0,30 & 1,90 & 1,16 & 7,31 & 0,11 & 0,72 \\
\hline Máquinas e equipamentos & 0,07 & 0,47 & 0,00 & 0,00 & 0,01 & 0,09 & 0,07 & 0,47 & 0,26 & 1,69 \\
\hline Material elétrico e eletrônicos & 0,11 & 0,54 & 0,01 & 0,03 & 0,03 & 0,18 & 0,03 & 0,17 & 0,57 & 2,95 \\
\hline Material de transporte & 0,21 & 1,00 & 0,03 & 0,13 & 0,00 & 0,00 & 0,01 & 0,03 & 0,90 & 4,27 \\
\hline Indústrias diversas & 0,03 & 0,40 & 0,00 & 0,01 & 0,01 & 0,08 & 0,02 & 0,28 & 0,22 & 3,37 \\
\hline
\end{tabular}

Fonte: Resultados da pesquisa. 
TABELA A.2

Impactos na mão de obra da região Nordeste (2015)

\begin{tabular}{|c|c|c|c|c|c|c|c|c|c|c|}
\hline \multirow{2}{*}{ Setores } & \multicolumn{3}{|c|}{$\begin{array}{r}\text { Estados } \\
\text { Unidos } \\
\end{array}$} & \multicolumn{2}{|l|}{ África } & China & \multicolumn{2}{|c|}{ União Europeia } & \multicolumn{2}{|c|}{ Argentina } \\
\hline & Q & NQ & Q & NQ & Q & NQ & Q & NQ & Q & NQ \\
\hline Agricultura, silvicultura e exploração florestal & 1,06 & 28,34 & 0,26 & 7,04 & 8,41 & 223,71 & 6,24 & 165,96 & 0,06 & 1,71 \\
\hline Pecuária e pesca & 0,40 & 15,44 & 0,02 & 0,73 & 0,00 & 0,14 & 0,05 & 1,97 & 0,00 & 0,00 \\
\hline Mineração & 0,10 & 0,38 & 0,05 & 0,18 & 0,52 & 1,99 & 0,30 & 1,14 & 0,02 & 0,08 \\
\hline Alimentos, bebidas e fumo & 2,41 & 32,26 & 2,26 & 30,19 & 0,38 & 5,03 & 5,92 & 79,22 & 1,16 & 15,54 \\
\hline Têxtil, vestuário e calçados & 2,17 & 55,82 & 0,49 & 12,73 & 1,78 & 45,74 & 3,03 & 77,82 & 1,39 & 35,87 \\
\hline Madeira, papel e impressão & 3,31 & 34,76 & 0,18 & 1,85 & 10,77 & 113,21 & 10,40 & 109,28 & 0,00 & 0,02 \\
\hline Refino de petróleo, coque e álcool & 1,25 & 3,01 & 0,00 & 0,00 & 0,00 & 0,01 & 0,63 & 1,52 & 0,03 & 0,08 \\
\hline Outros produtos químicos e farmacêuticos & 4,13 & 11,24 & 0,95 & 2,59 & 0,86 & 2,33 & 3,88 & 10,56 & 4,35 & 11,84 \\
\hline Artigos de borracha e plástico & 3,74 & 43,40 & 0,19 & 2,25 & 0,58 & 6,73 & 2,08 & 24,07 & 1,45 & 16,75 \\
\hline $\begin{array}{l}\text { Cimento e outros produtos de minerais não } \\
\text { metálicos }\end{array}$ & 0,22 & 3,65 & 0,01 & 0,14 & 0,01 & 0,12 & 0,02 & 0,41 & 0,02 & 0,29 \\
\hline Metalurgia & 1,40 & 8,83 & 0,14 & 0,87 & 2,73 & 17,30 & 0,56 & 3,52 & 0,75 & 4,74 \\
\hline Máquinas e equipamentos & 0,08 & 0,51 & 0,04 & 0,23 & 5,58 & 36,75 & 0,25 & 1,67 & 0,10 & 0,65 \\
\hline Material elétrico e eletrônicos & 0,01 & 0,03 & 0,01 & 0,03 & 1,19 & 6,15 & 0,57 & 2,95 & 0,66 & 3,40 \\
\hline Material de transporte & 0,05 & 0,24 & 0,00 & 0,02 & 0,03 & 0,12 & 0,00 & 0,01 & 4,03 & 19,02 \\
\hline Indústrias diversas & 0,01 & 0,17 & 0,01 & 0,14 & 0,00 & 0,01 & 0,01 & 0,15 & 0,01 & 0,09 \\
\hline
\end{tabular}

Fonte: Resultados da pesquisa.

TABELA A.3

Impactos na mão de obra da região Sul (2015)

\begin{tabular}{|c|c|c|c|c|c|c|c|c|c|c|}
\hline \multirow{2}{*}{ Setores } & \multicolumn{2}{|c|}{ Estados Unidos } & \multicolumn{2}{|c|}{ África } & \multicolumn{2}{|c|}{ China } & \multicolumn{2}{|c|}{ União Europeia } & \multicolumn{2}{|c|}{ Argentina } \\
\hline & Q & NQ & Q & NQ & Q & NQ & Q & NQ & Q & NQ \\
\hline $\begin{array}{l}\text { Agricultura, silvicultura e exploração } \\
\text { florestal }\end{array}$ & 0,34 & 9,13 & 2,28 & 60,69 & 44,89 & 1194,43 & 1,83 & 48,63 & 0,06 & 1,66 \\
\hline Pecuária e pesca & 0,23 & 8,85 & 2,14 & 82,42 & 2,24 & 86,48 & 2,73 & 105,30 & 0,15 & 5,91 \\
\hline Mineração & 0,00 & 0,02 & 0,00 & 0,00 & 0,01 & 0,02 & 0,01 & 0,02 & 0,01 & 0,03 \\
\hline Alimentos, bebidas e fumo & 3,75 & 50,18 & 5,32 & 71,13 & 3,20 & 42,82 & 29,61 & 396,18 & 0,76 & 10,15 \\
\hline Têxtil, vestuário e calçados & 3,44 & 88,41 & 0,36 & 9,24 & 1,88 & 48,39 & 5,76 & 148,05 & 1,83 & 47,08 \\
\hline Madeira, papel e impressão & 8,79 & 92,37 & 0,99 & 10,36 & 3,79 & 39,80 & 6,07 & 63,81 & 3,60 & 37,83 \\
\hline Refino de petróleo, coque e álcool & 0,69 & 1,65 & 0,00 & 0,00 & 0,00 & 0,00 & 0,09 & 0,22 & 0,32 & 0,77 \\
\hline Outros produtos químicos e farmacêuticos & 3,38 & 9,21 & 0,46 & 1,25 & 0,61 & 1,67 & 4,84 & 13,18 & 2,23 & 6,06 \\
\hline Artigos de borracha e plástico & 1,88 & 21,73 & 0,52 & 6,05 & 1,79 & 20,76 & 5,85 & 67,79 & 6,75 & 78,19 \\
\hline $\begin{array}{l}\text { Cimento e outros produtos de minerais } \\
\text { não metálicos }\end{array}$ & 1,34 & 22,67 & 0,17 & 2,79 & 0,01 & 0,15 & 0,23 & 3,91 & 0,57 & 9,63 \\
\hline
\end{tabular}


(Continuação)

\begin{tabular}{lcccccccccccc}
\hline & \multicolumn{1}{c}{ Setores } & \multicolumn{1}{c}{ Estados Unidos } & \multicolumn{2}{c}{ África } & & \multicolumn{2}{c}{ China } & \multicolumn{2}{c}{ União Europeia } & \multicolumn{2}{c}{ Argentina } \\
\cline { 2 - 12 } & Q & NQ & Q & NQ & Q & NQ & Q & NQ & Q & NQ \\
\hline Metalurgia & 0,75 & 4,73 & 0,15 & 0,96 & 0,16 & 1,01 & 0,41 & 2,56 & 0,78 & 4,92 \\
Máquinas e equipamentos & 8,72 & 57,37 & 2,42 & 15,91 & 1,40 & 9,19 & 9,81 & 64,56 & 9,34 & 61,47 \\
Material elétrico e eletrônicos & 2,66 & 13,72 & 0,88 & 4,53 & 0,49 & 2,52 & 3,19 & 16,49 & 1,41 & 7,30 \\
Material de transporte & 1,40 & 6,60 & 1,56 & 7,38 & 5,28 & 24,92 & 1,02 & 4,84 & 12,58 & 59,40 \\
Indústrias diversas & 3,74 & 57,97 & 0,61 & 9,38 & 0,03 & 0,49 & 2,54 & 39,31 & 0,67 & 10,39 \\
\hline
\end{tabular}

Fonte: Resultados da pesquisa.

Data da submissão: 7/6/2018

Primeira decisão editorial em: 2/1/2019

Última versão recebida em: 11/4/2019

Aprovação final em: 30/4/2019 